\title{
Technology Diffusion within Central Banking: The Case of Real-Time Gross Settlement*
}

\author{
Morten L. Bech and Bart Hobijn \\ Federal Reserve Bank of New York
}

\begin{abstract}
We examine the diffusion of the real-time gross settlement (RTGS) technology across the world's 174 central banks. RTGS reduces settlement risk and facilitates financial innovation in, for example, the settlement of foreign exchange trades. In 1985 only three central banks had implemented RTGS systems; by year-end 2006 that number had increased to ninetythree. We find that the RTGS diffusion process is consistent with a standard S-shaped curve. Real GDP per capita, the relative price of capital, and trade patterns explain a significant part of the cross-country variation in RTGS adoption. These determinants are remarkably similar to those that seem to drive cross-country adoption patterns of other technologies.
\end{abstract}

JEL Codes: C72, E58.

\section{Introduction}

Modern growth theory suggests that financial-sector development affects long-run economic growth. One of the most fundamental functions of the financial sector is to provide efficient mechanisms to make and receive payments. By reducing transaction costs, the payment system facilitates trade and allows greater specialization by agents in the economy. Over the past few decades, there has been a rapid increase in technological innovation in the financial sector.

${ }^{*}$ We thank Allison Fleming and Ariel Stern for research assistance. We are grateful for comments from Peter Allsopp and an anonymous referee. The views expressed in this paper are those of the authors and do not necessarily reflect those of the Federal Reserve Bank of New York or the Federal Reserve System. Corresponding author: Morten Bech, Research and Statistics Group, Federal Reserve Bank of New York, 33 Liberty Street, Third Floor, New York, NY 10045; Tel: (212) 720-6935; Fax: (212) 720-8363; E-mail: morten.bech@ny.frb.org. 
Nowhere is such innovation more apparent than in the electronification of means of payment.

In most countries, the payment system is provided by commercial banks in a symbiotic partnership with the central bank. Central banks tend to provide the medium to settle small payments (i.e., cash) and to support an interbank system that settles largevalue and time-critical payments. Historically, interbank payments have been settled via netting systems. In a netting system, the settlement of payments is deferred for some period of time, usually until the end of the business day. At the end of the deferment period, all payments are tallied up, and money is exchanged on either a bilateral or multilateral net basis among the participants. Commonly, this process is referred to as deferred net settlement (DNS).

The volume of interbank payments has increased dramatically over the last thirty years, mainly due to the aforementioned rapid financial innovation and the integration and globalization of financial markets. As the volume and value of transactions increased, central banks became worried about settlement risks inherent in netting systems. In particular, central banks were concerned about the potential for contagion (or even a systemic event) due to the unwinding of the net positions that would result if a participant failed to make good on its obligations when due. Consequently, over the last couple of decades, many countries have chosen to modify the settlement procedure employed by their interbank payment system with a view to reducing settlement risks and the potential for systemwide implications. Most central banks have opted for the implementation of a real-time gross settlement (RTGS) system. An RTGS system reduces settlement risk, as payments are settled individually and irrevocably on a gross basis in real time. This ensures immediate finality.

By 1985 three central banks had implemented an RTGS system. A decade later, that number had increased to sixteen, but RTGS was still utilized predominately by industrialized countries. In recent years, however, both transitional and developing countries have begun investing heavily in improving their financial systems, and now RTGS is a common choice for the interbank payment system. At the end of 2006, the use of RTGS systems had diffused to 93 of the world's 174 central banks. 
In this paper, we describe the diffusion of RTGS systems within the central banking community and seek to identify the determinants of adoption by using a new data set on the implementation of RTGS systems. A small, but growing, literature analyzes how and why commercial banks adopt new technologies (e.g., Hannan and McDowell 1984, Gowrisankaran and Stavins 2004, and Akhavien, Frame, and White 2005). However, to our knowledge, no studies have focused on central bank adoption of new technologies, including RTGS systems. ${ }^{1}$ This is surprising, given the key role the central bank plays in the financial sector. Moreover, the adoption decision by a central bank is potentially interesting in its own right, as it might be different from the profit considerations driving technology adoption in the private sector.

We analyze our data in two different ways. First, we consider the pattern of RTGS adoption over time and space. We estimate an S-shaped adoption curve that is a generalized version of those estimated by Griliches (1957) and find that, in all likelihood, it will take at least another fifteen years before RTGS is fully adopted. Second, we consider the main determinants of RTGS adoption using a discrete-time duration model, based on a logistic hazard rate. We find that the probability that a country adopts RTGS in a given year increases significantly with the level of real GDP per capita. Moreover, countries with a lower relative price of capital and countries whose major trading partners adopted RTGS are also more likely to adopt. This suggests that beyond market forces reflected by real GDP and capital costs, spillovers seem to play a significant role in the adoption of this financial innovation. These spillovers seem to disseminate mainly through trade relationships.

The structure of the rest of this paper is as follows. In the next section, we describe the role of the interbank payment systems as well as the features of netting and real-time gross settlement using the U.S. large-value payment system as an example. In section 3 we introduce our data on the adoption of RTGS, map out the

\footnotetext{
${ }^{1}$ Rogers (1995) defines diffusion as a process by which some type of innovation is communicated through certain channels over time and space among the members of a social system. An innovation is any kind of idea, object, or practice that members of the social system perceive as new.
} 
diffusion of RTGS across the world, and study the S-shaped nature of the world RTGS diffusion curve. Based on the theoretical and empirical literature on technology adoption, we review the potential determinants of RTGS adoption in section 4, and we briefly discuss our econometric methodology in section 5 . In section 6 we present our empirical results. We conclude with section 7 . A more detailed description of our data can be found in the appendix.

\section{Interbank Payment Systems and Real-Time Gross Settlement}

At the apex of the financial system are a number of critical financial markets that provide the means for agents to allocate capital and manage their risk exposures. Instrumental to the smooth functioning of these markets is a set of financial infrastructures that facilitate clearing and settlement. ${ }^{2}$ Many of these infrastructures use the interbank payment system to achieve final settlement. In addition, most central banks use the interbank payment system to implement monetary policy, and the system also serves as the platform for the interbank money market. An efficient and resilient interbank payment system reduces transaction costs for agents in the economy and is a precondition for the successful implementation of monetary policy and ensuring financial stability.

In the United States, there are two principal systems that settle interbank payments: the Federal Reserve's Fedwire Funds Transfer System ${ }^{\circledR}$ (Fedwire) and the Clearing House Inter-Bank Payments System (CHIPS), a private-sector enterprise. Commercial banks use Fedwire and CHIPS to handle large-value or time-critical payments, such as payments for the purchase, sale, and financing of securities transactions; foreign exchange transactions; the settlement of interbank purchases and sales of federal funds; the disbursement or repayment of loans; and the settlement of real

\footnotetext{
${ }^{2}$ Clearing is the process of transmitting and confirming payment orders or security transfers arising from market trades, as well as establishing, possibly by way of netting, final positions for settlement. Settlement is the act that discharges the obligations between two or more parties arising from the market trades. Settlement is final when it is irrevocable and unconditional. Ultimate settlement is sometimes used to denote final settlement in central bank money.
} 
estate transactions and other large-value purchases on behalf of customers. $^{3}$

Through Fedwire, participants initiate funds transfers that are immediate, final, and irrevocable when processed. Like other systems with these key features, Fedwire is an RTGS system. In fact, Fedwire is the world's oldest RTGS system. Its origins go back to 1918, when the Federal Reserve inaugurated a network of wire communications among the individual Reserve Banks. The new system of wire-initiated book entries allowed funds to be transferred on behalf of the member banks and significantly reduced the need for physical shipment of gold and currency. In the early 1970s, the Fedwire system migrated to a fully computerized platform, and settlement in "real time" was achieved. During the first year of Fedwire operation, the Federal Reserve Bank of New York processed around 100 wires per day; ten years later, the Bank was processing about 600 wires per day. Today, more than 7,500 participants across the twelve Reserve Banks originate an average of over 530,000 transfers per day. The value of transfers originated has seen tremendous growth. The annual turnover increased from around $\$ 100$ trillion in 1985 to over $\$ 570$ trillion in 2006, equivalent to an annual growth rate of over 8 percent (see figure 1).

The New York Clearing House Association organized CHIPS in 1970 for eight of its members to settle the dollar side of foreign exchange transactions and other large-value payments. Participation in CHIPS expanded gradually in the 1970s and 1980s to include other commercial banks, branches of foreign banks, and other financial institutions. CHIPS began as a deferred net settlement system. Until 1981, final settlement occurred on the morning of the next business day through the transfer of balances across the books of the Federal Reserve Bank of New York. A sharp increase in settlement volumes raised concerns that next-day settlement unduly exposed participants to various overnight and overweekend risks. In response, CHIPS began providing same-day settlement through Fedwire in August 1981.

Netting substantially reduces the amount of money needed to settle a given set of obligations. As a rough rule of thumb, $\$ 100$ in

\footnotetext{
${ }^{3}$ Several payment and securities settlement systems (including CHIPS) use Fedwire to square final positions over the course of the business day.
} 
Figure 1. Value of Payments Settled on Fedwire and CHIPS

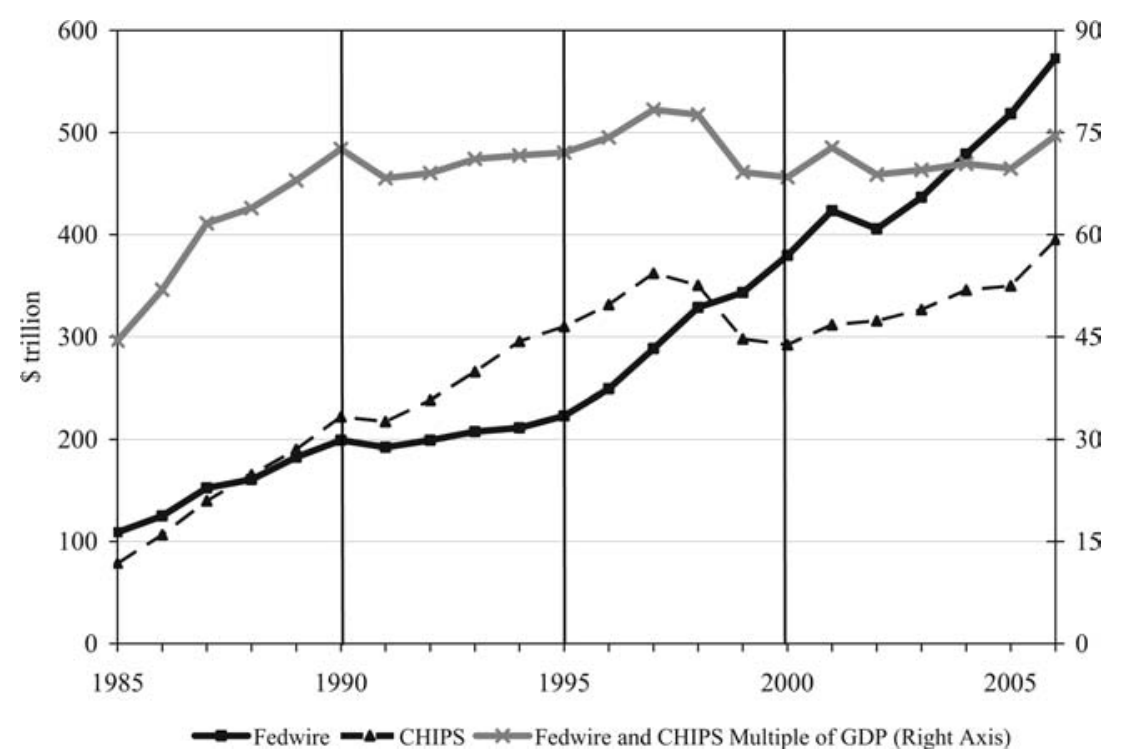

gross payments can be settled by an end-of-day net transfer of $\$ 1$. A major drawback of (unprotected) netting systems, however, is the risk that a party will default on its payment obligations. If even one participant fails to meet its net obligation when due, all processed payment orders involving that participant may be unwound and, as a result, other participants may fail to make full on their own net obligations. ${ }^{4}$ Such an event could conceivably set off a cascade of settlement failures that could disrupt the smooth functioning of the financial system. ${ }^{5}$ According to Humphrey's (1986) simulation study of two randomly selected business days in January 1983, the failure of a major CHIPS participant, given the rules at the time, could have caused dozens of large banks to fail, which could have

\footnotetext{
${ }^{4}$ It would be particularly troublesome if funds were credited to customers' accounts by banks expecting final settlement at a later time. This could translate into a credit exposure for those banks that have a limited ability to reclaim such funds.

${ }^{5}$ See Selgin (2004) for a critique of this line of reasoning.
} 
triggered a systemwide crisis. ${ }^{6}$ Accordingly, in response to the wishes of both participants and regulators, CHIPS moved in 2001 to a new settlement system that provides intraday finality. ${ }^{7}$

The current version of CHIPS is referred to as a hybrid system, as it combines features of DNS and RTGS. ${ }^{8}$ Currently, CHIPS has 45 participants (down from 142 in 1985) representing nineteen different countries. In 1985, CHIPS settled $\$ 78$ trillion, which increased to $\$ 362$ trillion in 1997. However, settlements over CHIPS dipped in the late 1990s, and it was not until 2006 (with $\$ 395$ trillion settled) that the previous peak was surpassed. As illustrated in figure 1, settlements over CHIPS were larger than those over Fedwire from 1988 to 1998. Seen over the entire period, the annual growth rate is comparable to that of Fedwire at almost 8 percent. Measured relative to the economic output of the United States, Fedwire and CHIPS settled payments equivalent to seventy-five times the gross domestic product in 2006. In other words, payments equivalent to the U.S. GDP run through the two systems on average every three-and-a-half business days.

\section{Diffusion of Real-Time Gross Settlement}

The U.S. experience with interbank payment systems is different from that of most countries in the sense that there have been two systems operating for the last thirty-five years and that RTGS was implemented before DNS. In the rest of the world, there is typically only one large-value interbank payment system per country, and prior to the 1980s, that system settled payments using deferred net settlement. As interbank payment systems around the world saw growth in the value of payments similar to that experienced by the United States, settlement risk issues emerged on the forefront of the payments policy agenda of the world's central banks. Because many aspects of settlement risk are eliminated in an RTGS system, many

\footnotetext{
${ }^{6}$ Similar simulation studies of interbank netting schemes in other countries have not found risks of the same magnitude. See, e.g., Angelini, Maresca, and Russo (1996) and Bech, Natorp, and Madsen (2002).

${ }^{7}$ For a description of the current CHIPS system, see www.chips.org.

${ }^{8}$ For a discussion of hybrid systems and new developments in large-value payment systems, see McAndrews and Trundle (2001) and Bank for International Settlements (2005).
} 
central banks began to consider this option. ${ }^{9}$ However, the reduction in risk comes at the cost of a greatly increased need for intraday liquidity to smooth the nonsynchronized payment flows. ${ }^{10}$

In the 1980s a number of Western European countries began implementing RTGS systems. By 1988, RTGS systems operated in five of the six major currencies (sterling being the other). During the early 1990s, RTGS adoption continued at a rate of roughly one country per year. In 1992, the Treaty of Maastricht created the foundation for the Economic and Monetary Union (EMU). A year later, the central banks within the European Union (EU) agreed that each member state should have an RTGS system. Furthermore, in 1995 it was decided to interlink the national RTGS systems through the Trans-European Automated Real-time Gross settlement Express Transfer (TARGET) system in order to facilitate the European Central Bank's (ECB) single monetary policy and to promote sound and efficient payment mechanisms in euros. ${ }^{11}$ These decisions led to a flurry of new systems and upgrades to existing ones. TARGET went live on January 4, 1999, and even EU countries that did not join the EMU at the outset were allowed to participate in the system.

As the ECB made RTGS a prerequisite for membership to the EMU, the prospective members in the rest of Europe began to implement RTGS as well. Furthermore, as hostilities ended in the Balkans in the late 1990s, governments began to rebuild their respective economies. They considered the establishment of sound and efficient financial systems a priority. RTGS systems were implemented with support from the EU, the International Monetary Fund (IMF), and

\footnotetext{
${ }^{9}$ RTGS can also help reduce settlement risk by facilitating payment versus payment or delivery versus payment in the settlement of foreign exchange and securities transactions, respectively. For a discussion of settlement risk in gross and net settlement systems, see Kahn, McAndrews, and Roberds (2003).

${ }^{10}$ Initially, central banks provided intraday credit for free to commercial banks. But this policy is no longer considered a viable option by central banks, as it exposes them (and ultimately the taxpayers), as guarantor of the finality of payments, to credit risk.

${ }^{11}$ The ECB also operates its own RTGS system for its account holders-the ECB payment mechanism (EPM). EPM is connected to TARGET and is used for settlement of euro positions arising from the EBA Clearing Company (through the EURO 1 system) and CLS, the continuous linked settlement system for foreign exchange transactions.
} 
the World Bank. With ongoing projects in Russia and Cyprus, the diffusion of RTGS in Europe is nearly complete.

In the late 1980s, the central banks of the Group of Ten $(\mathrm{G}-10)^{12}$ countries published the Angell and Lamfalussy reports, which study different aspects of interbank netting schemes. In 1990, the permanent Committee on Payment and Settlement Systems (CPSS) was created by the G-10 governors. The CPSS has focused on disseminating information on payment system design and has been instrumental in defining the norms and best practices for the central bank community in the area of payments. For example, in 1997, the CPSS published a report on real-time gross settlement that laid out general features as well as the specifics of the systems in operation in the G-10 countries. In 2002, the CPSS published a set of core principles for systemically important payment systems. These CPSS recommendations are now part of the toolkit of the Financial Sector Assessment Program (FSAP), jointly established by the IMF and the World Bank. The FSAP reviews seek to identify strengths and vulnerabilities in order to reduce the potential for financial crisis.

Outside Europe, the rate of adoption of RTGS since the mid1990s has been equally impressive. Australia and New Zealand implemented RTGS in 1998 and remain the only countries in Oceania that have gone live with RTGS. In Asia, the rate of RTGS implementation has been fairly steady; on average, about one country has adopted RTGS per year. Hong Kong is interesting in that RTGS is used to settle payments not only in the local currency but also in U.S. dollars and euros. Six countries in the Middle East have implemented RTGS. In Africa, the South African Reserve Bank (SARB) spearheaded adoption in 1998. Through the South African Development Community (SADC), ${ }^{13}$ the SARB has participated in developing and strengthening the financial infrastructure in the rest of southern Africa. As of 2006, eleven African central banks have implemented RTGS, many with the support of the World Bank.

\footnotetext{
${ }^{12}$ The G-10 countries are Belgium, Canada, France, Germany, Italy, Japan, Netherlands, Sweden, Switzerland, the United Kingdom, and the United States. In 1997 the Hong Kong Monetary Authority and the Monetary Authority of Singapore joined the Committee on Payment and Settlement Systems.

${ }^{13}$ The member states of the SADC are Angola, Botswana, the Democratic Republic of the Congo, Lesotho, Malawi, Mauritius, Mozambique, Namibia, Seychelles, South Africa, Swaziland, Tanzania, Zambia, and Zimbabwe.
} 
In the Western Hemisphere, Canada is an interesting case. It is the only G-10 country that has decided not to implement an RTGS system. Instead, Canada opted for a hybrid system that primarily employs multilateral netting by novation. The Canadian Large Value Transfer System is considered equivalent to RTGS in terms of finality, as the Bank of Canada provides an explicit guarantee of settlement in case of participant failure. In South America, Uruguay was the first country to adopt RTGS, in 1995. In 2006, seven of thirteen South American countries had adopted RTGS. RTGS implementation in Central America and the Caribbean has only started recently, but the Inter-American Development Bank is assisting the efforts to implement RTGS systems in the region. ${ }^{14}$

As illustrated in figure 2, the world RTGS adoption rate was about one central bank per year in the latter part of the 1980s and in the beginning of the 1990s. In the mid-1990s, however, the adoption

\section{Figure 2. Annual Number of Central Banks That Adopt RTGS}

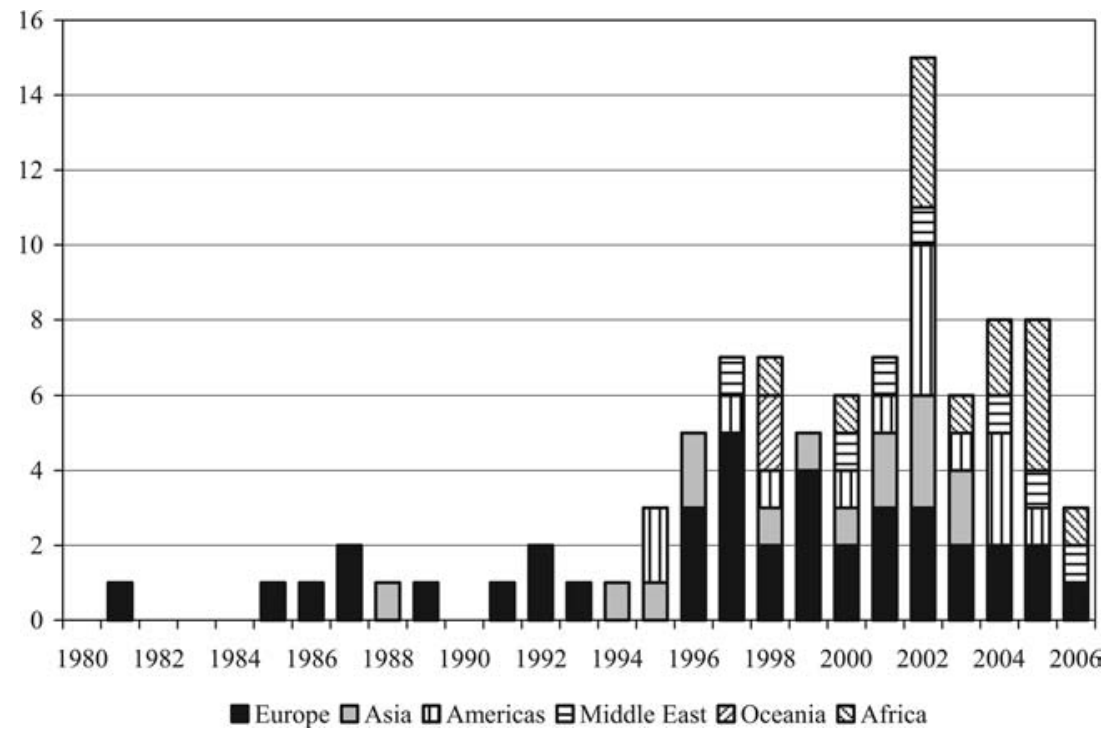

\footnotetext{
${ }^{14} \mathrm{~A}$ central-bank-specific account of the diffusion of RTGS is available in Bech (forthcoming).
} 
rate started to accelerate, with three central banks in 1995 and five central banks in 1996. The annual adoption rate has not dipped below three new central banks since. It peaked in 2002, when a total of fifteen central banks implemented new RTGS systems. By the end of 2006, 93 out of the 174 central banks in the world had adopted an RTGS system for their interbank payments, up from only a total of 3 central banks in 1985 (see figure 3).

\subsection{Diffusion Curve and Adopter Categories}

An important regularity in empirical studies of technology diffusion is that the rate of adoption follows a predictable intertemporal pattern (e.g., Griliches 1957). At first, the rate of adoption is slow. If the technology is ultimately a success, however, the rate of adoption starts to accelerate. Rapid adoption continues until a substantial share of the agents have adopted the technology. At this point, the rate of adoption levels off and eventually falls. This pattern implies that the share of adopters follows a sigmoidal, or S-shaped, curve as a function of time, as illustrated in figure 4.

An extensive literature spanning many disciplines has used logistic curves to model and predict growth and adoption data. The choice of a particular functional form is often somewhat arbitrary. For our application, we use a generalized logistic model proposed by Richards (1959) to fit the share of central banks that have adopted RTGS at time $t$, denoted by $a_{t}$. Specifically, we have

$$
a_{t}=\frac{1}{\left(1+\kappa \exp \left(-\gamma\left(t-t_{\max }\right)\right)^{1 / \kappa}\right)}+\varepsilon_{t},
$$

where $\gamma$ is the rate at which growth initially accelerates, $t_{\max }$ is the time at which the rate of adoption is highest (i.e., the inflection point of the curve), and $\kappa$ is a shape parameter that determines whether the point of inflection is closer to the lower or the upper asymptote. If $\kappa$ is equal to 1 , then the curve is symmetric around the median.

In accordance with the stylized fact from studies on the adoption of other technologies, we find that the diffusion of RTGS thus far is consistent with an S-shaped pattern over time. The curve of equation (1) was fitted using nonlinear least squares. The estimated 
Figure 3. Adoption of RTGS in 1985, 1995, and 2006
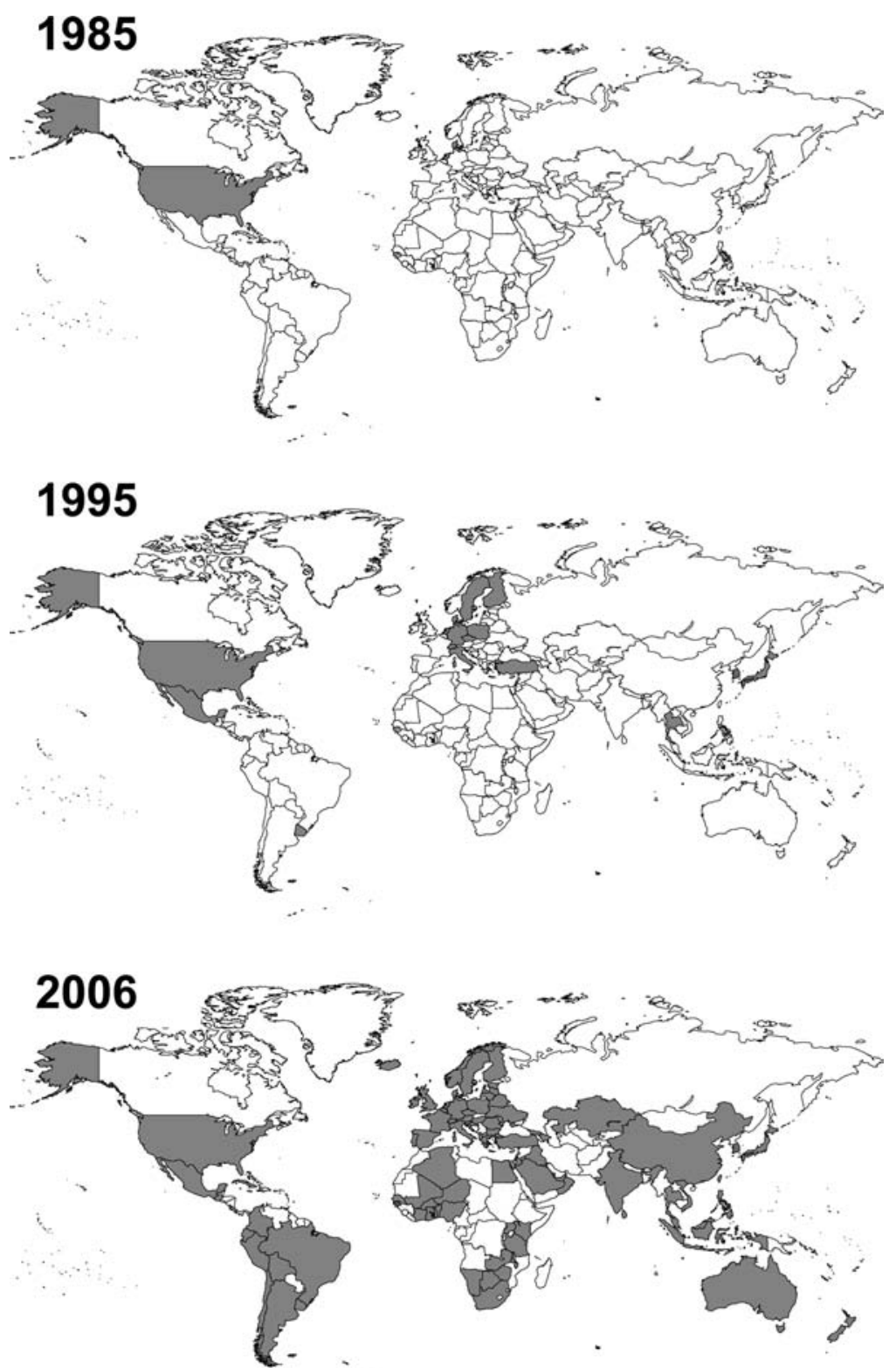


\section{Figure 4. Stylized Sigmoidal Adoption Curve and Adopters Categories}

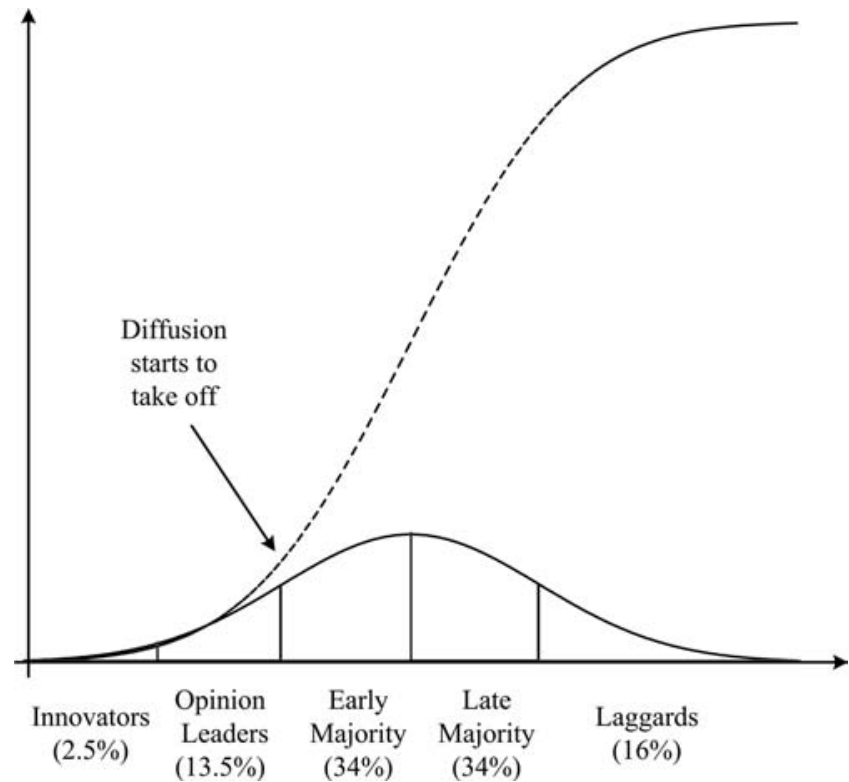

parameters and standard errors are given in table 1. The actual and fitted share of central banks that have adopted RTGS are shown in figure 5 . The overall fit of the curve is good, but the time of maximum growth is estimated to be 2004, not 2002, as found in sample. The shape parameter is found to be significantly different from 1, implying a degree of asymmetry.

The estimated generalized logistic curve suggests that the diffusion of RTGS will continue at a rapid pace until around 2010, at which time it will start to slow down. According to our estimates, the last 1 percent of central banks will not adopt until 2020. Predictions about the tails of the adoption curve do, however, depend a lot on the particular functional form chosen and thus have to be considered, at best, as only indicative of the pace of adoption.

Rogers (1995) classifies agents into five categories that reflect their "innovativeness," or predisposition to adopt a new technology, based on how early or late they adopt relative to the median adopter, as illustrated in figure 5 . The rate of adoption is assumed to follow a bell curve over time. The first 2.5 percent of adopters (i.e., those for which the time of adoption occurs more than two standard 


\section{Table 1. Estimated Coefficients for Logistic Adoption Curve}

\begin{tabular}{|l|c|c|c|}
\hline Coefficient & $t_{\max }$ & $\gamma$ & $\kappa$ \\
\hline Value & $2004^{* *}$ & $0.27^{* *}$ & $1.27^{* *}$ \\
Standard Error & .019 & 0.02 & 0.016 \\
\hline Note: ${ }^{* *}$ denotes significance at the 5 percent level (two-sided). \\
\hline
\end{tabular}

Figure 5. Actual and Fitted Adoption Rates of RTGS (Generalized Logistic)

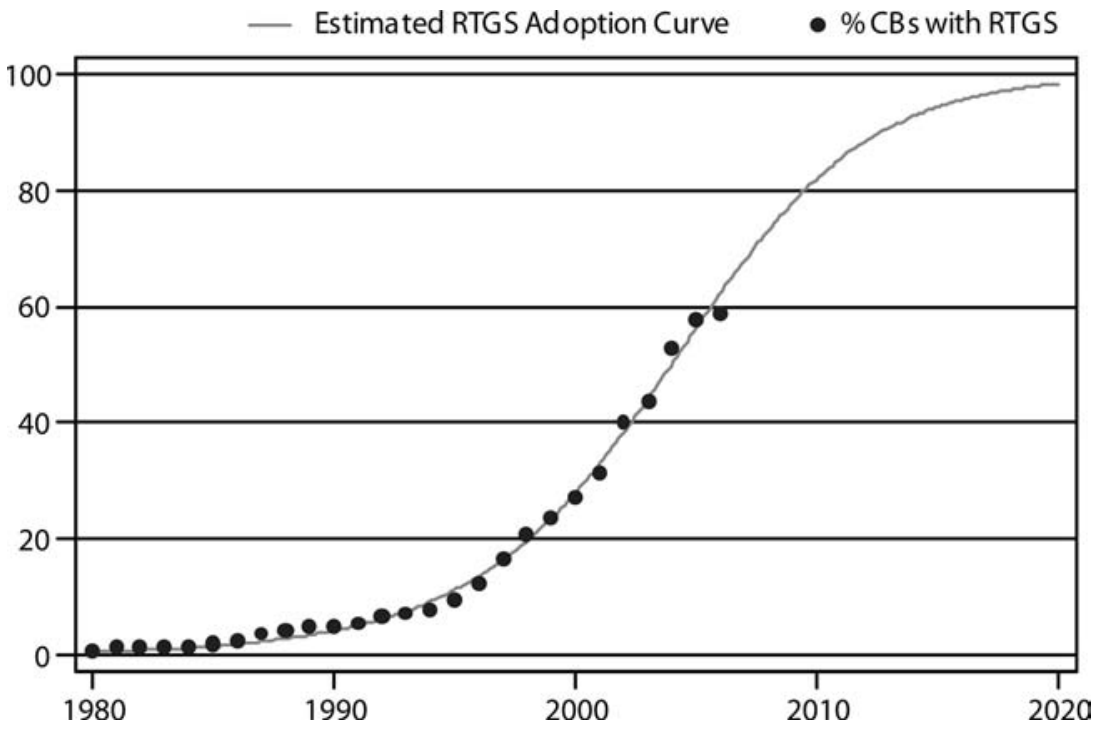

deviations earlier than the median agent) are labeled innovators. The following 13.5 percent (i.e., those for which the time of adoption is between one and two standard deviations earlier than the median adoption time) are labeled opinion leaders. The adoption time of the last opinion leaders corresponds to the first inflection point of the bell curve (i.e., where the rate of adoption takes off). The early majority is the next 34 percent of adopters up to the median, while the late majority is the 34 percent above the median. These two majority groups reflect those agents that adopt within one standard deviation of the median agent. The remaining 16 percent of adopters are called laggards. 
Rogers's (1995) classification implies that central banks that adopted RTGS prior to 1987 are considered innovators. Central banks that adopted RTGS between 1986 and 1998 are opinion leaders. Central banks that adopted RTGS from 1998 through 2004 belong to the early majority, and the most recent adopters are in the late majority. Interestingly, but not surprisingly, we find that all the central bank members of the CPSS belong to either the group of innovators or opinion leaders (see table 2). Moreover, many central banks belonging to the early and late majorities explicitly cite the recommendations put forward by the CPSS as a reason for implementing RTGS.

\section{Determinants of RTGS Diffusion}

In economic theories (e.g., Jensen 1982 and Jovanovic and Lach 1989) of technology diffusion, agents - usually firms - adopt a technology up to the point where the adoption cost equals the expected present discounted value of future private profits. Empirical analyses thus seek to identify the determinants of the adoption costs and the future profits. For example, Hannan and McDowell (1984) base their empirical investigation of automated teller machine (ATM) adoption on the presumption that "an innovation will appear more attractive to a potential adopter, the greater the positive differential between profits obtainable with and without the innovation."

However, as argued by, e.g., Blix, Daltung, and Heikensten (2003), central banking has certain features that make it quite different from the operations of private firms. Central banks tend not to operate for the single goal of profit maximization. They are instead charged with pursuing multiple public policy goals such as monetary and financial stability as well as the smooth operation of the payment system. Moreover, central banks often face soft budget constraints that may lead to less pressure to achieve cost efficiency.

Lester, Millard, and Willison (2006) provide a theoretical model of RTGS adoption. They argue that deferred net settlement is less costly due to the higher information and communication technology (ICT) costs associated with an RTGS environment. If these costs fall, then the settlement risk reduction achieved in a real-time gross settlement system may be enough to justify a switch from deferred net settlement. As in any theoretical model of payment systems, 
Table 2. Central Banks That Have Adopted RTGS and Their Respective Adoption Years

\begin{tabular}{|c|c|}
\hline Central Bank & Year \\
\hline \multicolumn{2}{|c|}{ Innovators } \\
\hline $\begin{array}{l}\text { Federal Reserve System } \\
\text { Danish National Bank } \\
\text { Dutch Central Bank } \\
\text { The Riksbank (Sweden) }\end{array}$ & $\begin{array}{l}1918 \\
1981 \\
1985 \\
1986\end{array}$ \\
\hline \multicolumn{2}{|c|}{ Opinion Leaders } \\
\hline $\begin{array}{l}\text { Bundesbank (Germany) } \\
\text { Swiss National Bank } \\
\text { Bank of Japan } \\
\text { Bank of Italy } \\
\text { Bank of Finland } \\
\text { Central Bank of the Republic of Turkey } \\
\text { State Bank of Czechoslovakia } \\
\text { National Bank of Poland } \\
\text { Bank of Korea (South Korea) } \\
\text { Central Bank of Uruguay } \\
\text { Bank of Mexico } \\
\text { Bank of Thailand } \\
\text { Bank of England } \\
\text { National Bank of Kazakstan } \\
\text { Hong Kong Monetary Authority } \\
\text { National Bank of Belgium } \\
\text { Bank of Portugal } \\
\text { Bank of Spain } \\
\text { Central Bank of Argentina } \\
\text { National Bank of Austria } \\
\text { Central Bank of Ireland } \\
\text { Bank of Norway } \\
\text { Bank of France } \\
\text { Saudi Arabian Monetary Agency }\end{array}$ & $\begin{array}{l}1987 \\
1987 \\
1988 \\
1989 \\
1991 \\
1992 \\
1992 \\
1993 \\
1994 \\
1995 \\
1995 \\
1995 \\
1996 \\
1996 \\
1996 \\
1996 \\
1996 \\
1997 \\
1997 \\
1997 \\
1997 \\
1997 \\
1997 \\
1997\end{array}$ \\
\hline \multicolumn{2}{|c|}{ Early Majority } \\
\hline $\begin{array}{l}\text { Bank of Slovenia } \\
\text { Bank of the Republic of Belarus }\end{array}$ & $\begin{array}{l}1998 \\
1998\end{array}$ \\
\hline
\end{tabular}

(continued) 
Table 2 (continued). Central Banks That Have Adopted RTGS and Their Respective Adoption Years

\begin{tabular}{|c|c|}
\hline Central Bank & Year \\
\hline \multicolumn{2}{|c|}{ Early Majority (continued) } \\
\hline Central Bank of Colombia & 1998 \\
\hline Monetary Authority of Singapore & 1998 \\
\hline Reserve Bank of Australia & 1998 \\
\hline Reserve Bank of New Zealand & 1998 \\
\hline South African Reserve Bank & 1998 \\
\hline Croatian National Bank & 1999 \\
\hline Central Bank of Luxembourg & 1999 \\
\hline Bank of Greece & 1999 \\
\hline Central Bank of Malaysia & 1999 \\
\hline National Bank of Hungary & 1999 \\
\hline Central Bank of Peru & 2000 \\
\hline Central Bank of Iceland & 2000 \\
\hline Qatar Central Bank & 2000 \\
\hline Bank of Indonesia & 2000 \\
\hline Bank of Latvia & 2000 \\
\hline Bank of Mauritius & 2000 \\
\hline Central Bank of the United Arab Emirates & 2001 \\
\hline State Bank of Vietnam & 2001 \\
\hline National Bank of the Republic of Macedonia & 2001 \\
\hline National Bank of Azerbaijan & 2001 \\
\hline Central Bank of Bosnia and Herzegovina & 2001 \\
\hline Central Bank of Netherlands Antilles & 2001 \\
\hline National Bank of Georgia & 2001 \\
\hline Central Bank of Costa Rica & 2001 \\
\hline Central Bank of Cuba & 2001 \\
\hline Central Bank of Brazil & 2002 \\
\hline Central Bank of Malta & 2002 \\
\hline Central Bank of the Philippines & 2002 \\
\hline Bank of Estonia & 2002 \\
\hline Bank of Namibia & 2002 \\
\hline Reserve Bank of Malawi & 2002 \\
\hline Reserve Bank of Zimbabwe & 2002 \\
\hline Central Bank of Barbados & 2002 \\
\hline Bank of Ghana & 2002 \\
\hline
\end{tabular}


Table 2 (continued). Central Banks That Have Adopted RTGS and Their Respective Adoption Years

\begin{tabular}{|c|c|}
\hline Central Bank & Year \\
\hline \multicolumn{2}{|c|}{ Early Majority (continued) } \\
\hline The Peoples Bank of China & 2002 \\
\hline Central Bank of Jordan & 2002 \\
\hline Central Bank of China (Taiwan) & 2002 \\
\hline Central Bank of Bulgaria & 2002 \\
\hline Bank of Botswana & 2003 \\
\hline Reserve Bank of India & 2003 \\
\hline National Bank of the Slovak Republic & 2003 \\
\hline National Bank of Serbia & 2003 \\
\hline Central Bank of Ecuador & 2003 \\
\hline Central Bank of Sri Lanka & 2003 \\
\hline Central Bank of Kuwait & 2004 \\
\hline Central Bank of Chile & 2004 \\
\hline Bank of Tanzania & 2004 \\
\hline Central Bank of Bolivia & 2004 \\
\hline Bank of Albania & 2004 \\
\hline Bank of Lithuania & 2004 \\
\hline Central Bank of West African States & 2004 \\
\hline Bank of Zambia & 2004 \\
\hline Central Bank of Trinidad and Tobago & 2004 \\
\hline \multicolumn{2}{|c|}{ Late Majority } \\
\hline National Bank of Romania & 2005 \\
\hline Bank of Guatemala & 2005 \\
\hline Bank of Uganda & 2005 \\
\hline National Bank of Ukraine & 2005 \\
\hline Central Bank of Montenegro & 2005 \\
\hline Central Bank of Kenya & 2005 \\
\hline Central Bank of Oman & 2005 \\
\hline Central Bank of Nigeria & 2005 \\
\hline National Bank of Moldova & 2006 \\
\hline Bank of Algeria & 2006 \\
\hline Central Bank of Iraq & 2006 \\
\hline
\end{tabular}


a switch from one system to another generally requires a facilitator that coordinates the choices of all market participants. This is where the public policy role of the central bank comes in.

Hence, our study of RTGS adoption is importantly different from other empirical studies of technology adoption (e.g., Griliches 1957, Mansfield 1961, Gort and Klepper 1982, Jovanovic and Lach 1989, and Skinner and Staiger 2005). These studies focus on the adoption of technologies by individuals or firms that have a profit incentive. Such a market incentive is only indirectly present in a central bank's decisions to adopt RTGS systems. The set of factors taken into account by central banks when assessing the benefits of adopting a new technology is potentially much bigger than that of private-sector firms.

Technology is an input in the production function of clearing and settlement services, just as labor and capital are. Keller (2004) highlights two key aspects of technology that are applicable in our context as well. First, technology is a nonrival in the sense that the marginal costs of an additional agent using the technology are negligible and that the adoption of RTGS by one central bank does not in any way hinder another central bank from adopting. Second, the returns to technological investments are partly private and partly public.

The basic premise of our analysis is that a central bank that has not yet adopted RTGS will adopt at such time $\tau_{i}$ when the perceived (present discounted) value of benefits equals or exceeds the (present discounted) cost of adoption. As argued above, we do not necessarily interpret the costs and benefits here in the neoclassical sense of a profit function, but instead interpret them in the broader context of both private and social costs and benefits.

We regard an RTGS system to be an irreversible settlement process innovation with a considerable ICT investment embedded in it. The adoption of an RTGS is virtually impossible to reverse due to the central role of the interbank payment system and its many interconnections and interdependencies with other financial infrastructures. As other clearing and settlement mechanisms come to rely on instant finality in real time, changing their modus operandi becomes increasingly expensive or even infeasible. Moreover, the implementation of a specific settlement process imposes certain requirements in terms of ICT. For example, DNS requires batch-based computing and communication capabilities with participants, while RTGS requires real-time computing and communication. 
Economic theory and evidence on technology adoption provide us with guidance on the set of potentially significant determinants of perceived value and costs. In the rest of this section, we discuss the potential determinants of innovativeness and the method by which we approximate them in our empirical analysis. We limit ourselves to a brief description of the data here. The underlying details, definitions, and sources are provided in the appendix. The cost and benefit factors we identify for our empirical analysis can be classified into two groups. The first group comprises direct indicators of costs and benefits. The second consists of the effects the actions of other central banks have on a particular central bank's cost and benefit perception.

Investment Price Index. Our main indicator of direct adoption costs is the price of investment goods from the Penn World Table (Heston, Summers, and Aten 2002). We use this as a proxy for the price of the ICT equipment that is necessary to execute settlements in an RTGS system. Hence, we expect countries in which ICT is cheaper, as reflected in a lower investment price, to adopt RTGS more quickly. We are aware that our investment price measure is not ICT specific. For this reason, we also use personal computers per capita as an additional proxy, where our main assumption is that more personal computers reflect lower ICT prices and implementation costs.

Education. Brynjolfsson and Hitt (2000) provide evidence that the costs of physical capital and software are only a small part of the total costs involved in implementing ICT-related process innovations in the U.S. private sector. A large part of the cost of implementation has to do with the acquisition of the knowledge about how to use and benefit from the new process, which mainly involves skilled labor inputs. That is, adoption costs are lower if employees' pre-RTGS skills and knowledge help them learn the best way to use RTGS systems more quickly, as pointed out in Nelson and Phelps (1966). This is often referred to as the new technology being "appropriate" for the existing endowments (see, e.g., Basu and Weil 1998).

Since we use a measure of education of the overall workforce, our measure also includes the skill level of the (potential) users of the RTGS system. Because of capital-skill complementaries, an RTGS system increases the productivity of educated users more than that 
of other users. As a consequence, we expect the benefits of RTGS to be higher in countries with a more educated workforce.

Independent of the cost versus benefit interpretation of education for RTGS adoption, we expect education to have an unambiguously positive effect on the probability of a central bank adopting an RTGS system.

Financial Market Development. On the direct benefits side, central banks themselves are not assumed to pursue a profit objective per se. They are, however, presumed to contribute to the efficiency, stability, and competitiveness of domestic financial markets. The main benefit of adopting an RTGS system is that it improves the efficiency of domestic financial markets, primarily by significantly reducing settlement risks.

Unfortunately, cross-country data on the amount of settlements on interbank payment systems is not available. This means we will have to use indirect proxy variables for the level of financial development and its effects on RTGS adoption. We use three proxy variables, shown by Levine, Loayza, and Beck (2000) to be correlated with GDP growth. These variables are liquid liabilities, which measure the financial depth of a country; the ratio of commercial to central bank assets, which measures the degree to which the private part of the banking sector allocates savings; and private credit issued by financial intermediaries to the private sector. The latter is the preferred measure of financial development of Levine, Loayza, and Beck (2000).

Real GDP per Capita and Population. Real GDP per capita seems to matter in almost all studies of cross-country technology adoption patterns (e.g., Caselli and Coleman 2001 and Comín and Hobijn 2004). Because the fixed setup costs of an RTGS system are, in large part, independent of the size of the market, while the benefits of an RTGS system, as in the reduction of the settlement risk, are increasing with the size of the market, we would expect to observe the adoption of RTGS to be subject to scale effects. These effects are similar to those in the endogenous growth literature (Jones 1995) in which a fixed innovation cost would imply that the endogenous growth rate would be increasing with market size. To the extent such scale effects exist, we expect the likelihood of adoption of RTGS to be higher in countries with a bigger population and a larger economy, as measured by GDP per capita. 
So far, we have focused on a central bank's adoption costs and benefits of implementing an RTGS system that does not depend on the actions of its counterparts. ${ }^{15}$ There are, however, several reasons to believe that the RTGS adoption decisions of central banks are likely to be interdependent.

First, the decision to adopt is influenced by competitive pressures from global financial markets. To the extent that an RTGS system provides benefits that enhance the competitiveness of the domestic financial markets or financial assets denominated in the currency of the central bank, such pressures may speed up or force the adoption decision. For example, a prerequisite for a currency to be part of the Continuous Linked Settlement (CLS) foreign exchange settlement system is the ability to make real-time transfers in central bank money. ${ }^{16}$

Second, just as is the case for personal computers (e.g., Goolsbee and Klenow 2002), the adoption of RTGS is subject to network externalities. That is, given international financial integration, it is more beneficial for a central bank to adopt an RTGS system when this allows access to a broad network of other countries' RTGS systems. This consideration seems to have been an important driving force behind the EU's requirement that countries have an RTGS system in place before joining the monetary union.

Third, given the many cooperative structures set up among central banks (like the Bank for International Settlements and the European Central Bank), as well as the many other interlinkages between central banks (such as their historical linkages), it is very likely that the knowledge acquired through experiences with RTGS systems spills over to other central banks and helps them make their

\footnotetext{
${ }^{15}$ It is difficult to measure central bank efficiency (see Blix, Daltung, and Heikensten 2003 for a discussion). For example, the functions carried out by central banks vary significantly across countries. In fact, as noted by Brione (2006), it is hard to get an idea of the actual operating expenses of central banks, even across the OECD, let alone the rest of the world.

${ }^{16}$ CLS Bank International is currently the leading settlement institution for foreign exchange transactions. It is an industry-owned bank, chartered in the United States as an Edge corporation and supervised by the Federal Reserve System. CLS was founded in response to concerns raised by the G-10 central banks about settlement risk in foreign exchange transactions. It began operations in September 2002 and now settles transactions in fifteen currencies for a sizable share of the foreign exchange market.
} 
respective adoption decisions. Spillovers of this type have been extensively documented as they relate to R\&D and trade flows (see, e.g., Coe and Helpman 1995), and they are likely to be an important factor in the diffusion of payments systems as well.

Fourth, central banks do not necessarily have to install and develop the ICT component involved with the RTGS adoption themselves. Several private companies have entered the marketplace and have begun to offer "off-the-shelf" standardized software solutions. Currently, there are at least five providers that have built RTGS systems in more than one country. ${ }^{17}$ The possibility of sharing development costs across customers and competition among providers has presumably lowered the cost of implementing RTGS and hence made it feasible for more countries to adopt.

The second point outlined above is known as a network spillover, while the third and fourth points are known as knowledge spillovers. ${ }^{18}$ These are two types of indicators that we include in our analysis to capture interdependencies of central banks' RTGS adoption decisions.

Membership of International Organizations. To capture knowledge spillovers that arise from countries sharing information and jointly defining policy goals and standards in international organizations, we control for central banks being members of the Bank for International Settlements (BIS), countries being member states of the European Union, and countries being member states of the South African Development Council.

To the extent that membership in these organizations provides earlier access to knowledge about RTGS, we expect membership in these organizations to have a positive impact on the likelihood of a central bank adopting an RTGS system.

\footnotetext{
${ }^{17}$ These providers are LogicaCMG plc of the United Kingdom, CMA Small System AB of Sweden, the joint venture of Perago Ltd of South Africa and SIA SpA of Italy, Montran Corporation of the United States, and BCS Information Systems of Singapore.

${ }^{18}$ We are using the term spillover loosely here. The interdependencies in the decisions of central banks that we describe are only spillovers in a pure economic sense if, when making adoption decisions, central banks do not take into account the positive effects that their RTGS adoption decisions have on their counterparts. If central banks do not internalize these effects, the rate of adoption of RTGS around the world would be inefficiently low.
} 
Bilateral Trade. To capture knowledge and network spillovers from the countries that interact most with each other economically, we calculate the trade-weighted fraction of countries' trading partners that have adopted an RTGS system. ${ }^{19}$ This measure is very similar in spirit to the R\&D spillover measure that Coe and Helpman (1995) use in their analysis and, just as in Coe and Helpman (1995), we expect it to have a positive effect on (RTGS) technology adoption.

\section{Econometric Analysis}

In this section, we outline our econometric approach. Let $v_{i t}^{*}$ denote the perceived value of the RTGS system for central bank $i$ at time $t$, and let $c_{i t}^{*}$ denote the cost of adoption. In practice, we observe neither the perceived benefits nor the costs of adopting an RTGS system for any central bank. However, we assume that both $v_{i t}^{*}$ and $c_{i t}^{*}$ can be represented by a linear combination of a set of observable proxy variables. These are the variables described in section 4 . We denote the vector with these variables as $\mathbf{x}_{i t}$. Specifically, we assume

$$
\begin{aligned}
v_{i t}^{*} & =\mathbf{x}_{i t}^{\prime} \boldsymbol{\theta}_{v}+\varepsilon_{i t}^{v}, \\
c_{i t}^{*} & =\mathbf{x}_{i t}^{\prime} \boldsymbol{\theta}_{c}+\varepsilon_{i t}^{c},
\end{aligned}
$$

where $\boldsymbol{\theta}_{v}$ and $\boldsymbol{\theta}_{c}$ are vectors of unknown perceived marginal benefit and perceived marginal cost parameters. $\varepsilon_{i t}^{v}$ and $\varepsilon_{i t}^{c}$ are country- and time-specific random variables. The adoption time, $\tau_{i}$, of RTGS for central bank $i$ satisfies

$$
\tau_{i}=\underset{t}{\arg \min }\left\{t \mid y_{i t}^{*} \geq 0\right\},
$$

where

$$
y_{i t}^{*}=v_{i t}^{*}-c_{i t}^{*}=\mathbf{x}_{i t}^{\prime}\left(\boldsymbol{\theta}_{v}-\boldsymbol{\theta}_{c}\right)+\varepsilon_{i t}^{v}-\varepsilon_{i t}^{c}=\mathbf{x}_{i t}^{\prime} \boldsymbol{\theta}+\varepsilon_{i t}
$$

is the net benefit of adopting RTGS at time $t$. We do not observe this net benefit; it is a latent variable. What we do observe is whether an RTGS system is adopted by a central bank at time $t$ in our sample period, $\{1, \ldots, T\}$.

\footnotetext{
${ }^{19}$ We limit ourselves to the ten largest trading partners for each country.
} 
Let $y_{i t}$ be a binary variable that equals 1 if central bank $i$ has adopted RTGS at time $t$ and 0 otherwise. As the adoption process of RTGS is still ongoing, there are two types of central banks in our sample: (i) central banks that have already adopted - the uncensored part of the sample - and (ii) central banks that have not yet adopted - the censored part of our sample. For central banks that adopt RTGS at time $\tau_{i} \leq T$, we observe the binary variable $y_{i t}=0$ for all $t<\tau_{i}$ and $y_{i t}=1$ for $t \geq \tau_{i}$. This sequence of observations implies that the net benefit of adopting for central bank $i$ was negative (i.e., $y_{i t}^{*}<0$ ) for $t=1, \ldots, \tau_{i}-1$ and positive (i.e., $y_{i t}^{*} \geq 0$ ) for $t=\tau_{i}$. The assumed irreversibility of the RTGS adoption decision means that the observations for $t>\tau_{i}$ are of no empirical relevance for our analysis. For central banks in the censored part of our sample -i.e., those that have yet to adopt RTGS - we observe $y_{i t}=0$ for all $t=1, \ldots, T$. This implies that the latent net benefit of RTGS adoption was negative for every period up to time $T$.

Following the approach of Allison (1982), we assume that $\varepsilon_{i t}$ is independently, logistically distributed - in our case across countries and over time. This allows us to write our model as a logistic hazard model and to relate the probability of RTGS adoption to the cross-country and time variation in the covariates $\mathbf{x}_{i t} .{ }^{20}$

The probability that central bank $i$ adopts an RTGS system at time $\tau_{i}=t$ equals

$$
p\left(\tau_{i}=t\right)=\prod_{s=t}^{T} p\left(y_{i s}=1 \mid Y_{s-1}\right) \cdot \prod_{u=2}^{t-1} p\left(y_{i u}=0 \mid Y_{u-1}\right) \cdot p\left(y_{i 1}=0\right),
$$

where $Y_{t-1}$ denotes the set of observations up to and including $y_{i t-1}$. However, due to the irreversible nature of the adoption decision,

$$
p\left(y_{i s}=1 \mid \ldots, y_{i u}=1, \ldots\right)=1 \text { for all } s>u .
$$

Hence, the only observations that are relevant for calculating the probability are the ones before the central bank adopts and the one at the time that it adopts. From equations (6) and (7), we have

$$
p\left(\tau_{i}=t\right)=p\left(y_{i t}=1 \mid Y_{t-1}\right) \cdot \prod_{s=2}^{t-1} p\left(y_{i s}=0 \mid Y_{s-1}\right) \cdot p\left(y_{i 1}=0\right) .
$$

\footnotetext{
${ }^{20}$ Our technology adoption analysis is similar to the retirement decision analysis in Ashenfelter and Card (2002).
} 
In contrast, for central banks that do not adopt RTGS within our sample period (i.e., the censored part of the sample), we observe $y_{i t}=0$ for all $t$. We have

$$
p\left(\tau_{i}>T\right)=\prod_{s=2}^{T} p\left(y_{i s}=0 \mid Y_{s-1}\right) p\left(y_{i 1}=0\right) .
$$

In practice, this means that, for our empirical analysis, we use data not only on central banks that have already implemented the system but also on central banks that have not yet done so. For the central banks that adopt, however, we only use information up to and including the time of adoption.

From equations (8) and (9), we can set up the likelihood function. Let the set of countries that have adopted RTGS by the end of the sample period be $A_{T}=\left\{i \mid \tau_{i} \leq T\right\}$. We have $p\left(y_{i t}=\right.$ $\left.1 \mid \mathbf{x}_{i t}\right)=p\left(y_{i t}^{*}>0 \mid \mathbf{x}_{i t}\right)=p\left(\varepsilon_{i t}>-\mathbf{x}_{i t}^{\prime} \boldsymbol{\theta}\right)$. Assuming that $y_{i 1}, \ldots, y_{i T}$ (conditional on $\mathbf{x}_{i 1}, \ldots, \mathbf{x}_{i T}$ ) are independent and that $\varepsilon_{i t}$ has a logistic distribution $\Lambda(\varepsilon)=p\left(\varepsilon_{i t}<\mathbf{x}_{i t}^{\prime} \boldsymbol{\theta}\right)$, the likelihood function becomes

$$
\begin{aligned}
\mathcal{L}\left(\boldsymbol{\theta} ; \tau_{i}\right) & =\prod_{i \in A_{T}} p\left(\tau_{i}=t \mid \mathbf{x}_{i t}\right) \cdot \prod_{i \notin A_{T}} p\left(\tau_{i}>T \mid \mathbf{x}_{i t}\right) \\
& =\prod_{i \in A_{T}}\left[\prod_{t=1}^{\tau_{i}} p\left(y_{i t}=0 \mid \mathbf{x}_{i t}\right)\right] p\left(y_{i t}=1 \mid \mathbf{x}_{i t}\right) \cdot \prod_{i \notin A_{T}} \prod_{t=1}^{T} p\left(y_{i t}=0 \mid \mathbf{x}_{i t}\right) \\
& =\prod_{i \in A_{T}}\left[\prod_{t=1}^{\tau_{i}} 1-\Lambda\left(\mathbf{x}_{i t}^{\prime} \boldsymbol{\theta}\right)\right] \Lambda\left(\mathbf{x}_{i t}^{\prime} \boldsymbol{\theta}\right) \cdot \prod_{i \notin A_{T}} \prod_{t=1}^{T} 1-\Lambda\left(\mathbf{x}_{i t}^{\prime} \boldsymbol{\theta}\right) .
\end{aligned}
$$

Our specification implies that we can only estimate $\left(\boldsymbol{\theta}_{v}-\boldsymbol{\theta}_{c}\right)$, which is the excess benefit from a particular variable in $\mathbf{x}_{i, t}$. However, for proxy variables that we know affect only costs or only benefits (or for which we can reasonably conjecture the same), the coefficient can be interpreted as the cost or benefit parameter.

The above likelihood function is that of a logit model. Since the probability of adoption can be interpreted as a hazard rate in terms of a duration model, our empirical analysis can be interpreted as a discrete-time duration model with logistic, time-varying hazard rates. 


\section{Results}

Table 3 contains the estimated coefficients from the logistic-hazardrate model. Our sample covers 108 central banks from 1970 through 2000. We take an incremental approach for our analysis of the causes of technology adoption of RTGS. We start by presenting the core results for the explanatory variables that matter consistently across our model specifications. These are (i) real GDP per capita, (ii) population, (iii) education, and (iv) the investment price. For all of these variables, the estimated coefficients are significant and of the expected sign for all model specifications for which we have 100 countries or more. That is, larger countries (as reflected by population) with a higher standard of living (as reflected by real GDP per capita) and a higher level of human capital (as reflected by education) seem to be more likely to adopt an RTGS system than others.

Moreover, countries with a relatively low price of capital also are more likely to adopt. Jones (1994) finds that capital prices, especially those of machines, help explain cross-country variation in growth rates of real GDP per capita. Our results suggest that this variation might have to do with the ways in which these capital prices affect technology adoption decisions. That is, if these prices seem to be significant in explaining variation in the adoption of a technology by the public sector, they most likely matter even more for the adoption of technologies by the private sector where the profit motive is an even more powerful incentive for adoption decisions.

In terms of our spillovers proxies, we find that bilateral trade relationships with countries that have adopted RTGS significantly increase the probability of adoption. This is very much in line with the evidence on international R\&D spillovers, as in Coe and Helpman (1995). In terms of membership in international organizations, only membership of the South African Development Council seems to function as a significant catalyst of the RTGS adoption process. A country's membership in this organization significantly increases the per-period probability of adopting RTGS compared with its nonmember counterparts.

The financial development measures - i.e., those that proxy for financial markets benefits of RTGS - do not seem to explain much of the cross-country variation in the adoption of RTGS. The insignificance of these indicators is not due to their being highly correlated. 
Table 3. Estimated Coefficients for Logit Adoption Model

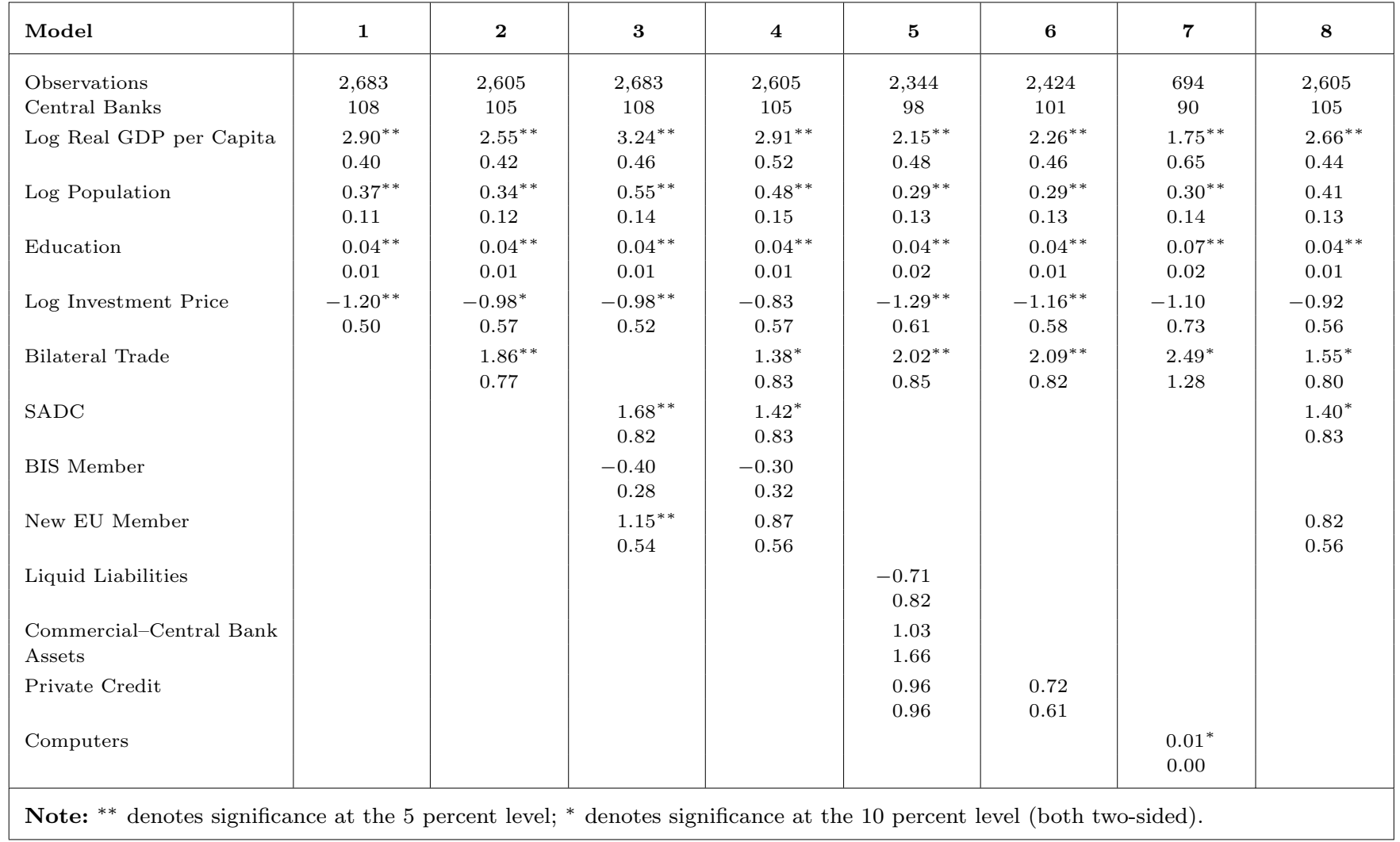


Even when we only include private credit, as in column 7 of table 3 , we do not find any significant effect of financial development on the probability of RTGS adoption beyond that which is already captured by including real GDP per capita among the regressors.

The adoption rate of personal computers per capita does seem to positively affect the probability of adoption of RTGS. This result, however, should be interpreted with caution because the small number of observations on personal computers per capita means that the coefficient is estimated with far fewer degrees of freedom than the other results.

To see how much the fitted cross-country variation in the adoption probability explains the cross-country adoption patterns, we present the results of an out-of-sample experiment in figure 6 . This figure plots the log of the fitted RTGS adoption probability, based on model 8 from table 3 , for the countries in the censored part of our sample against the actual adoption date, as well as the "2006 or later" date for countries that had not adopted RTGS by the end of 2005. The line is the average log of fitted probability of adoption in

Figure 6. Fitted 2000 Adoption Probabilities and Subsequent Adoption Dates

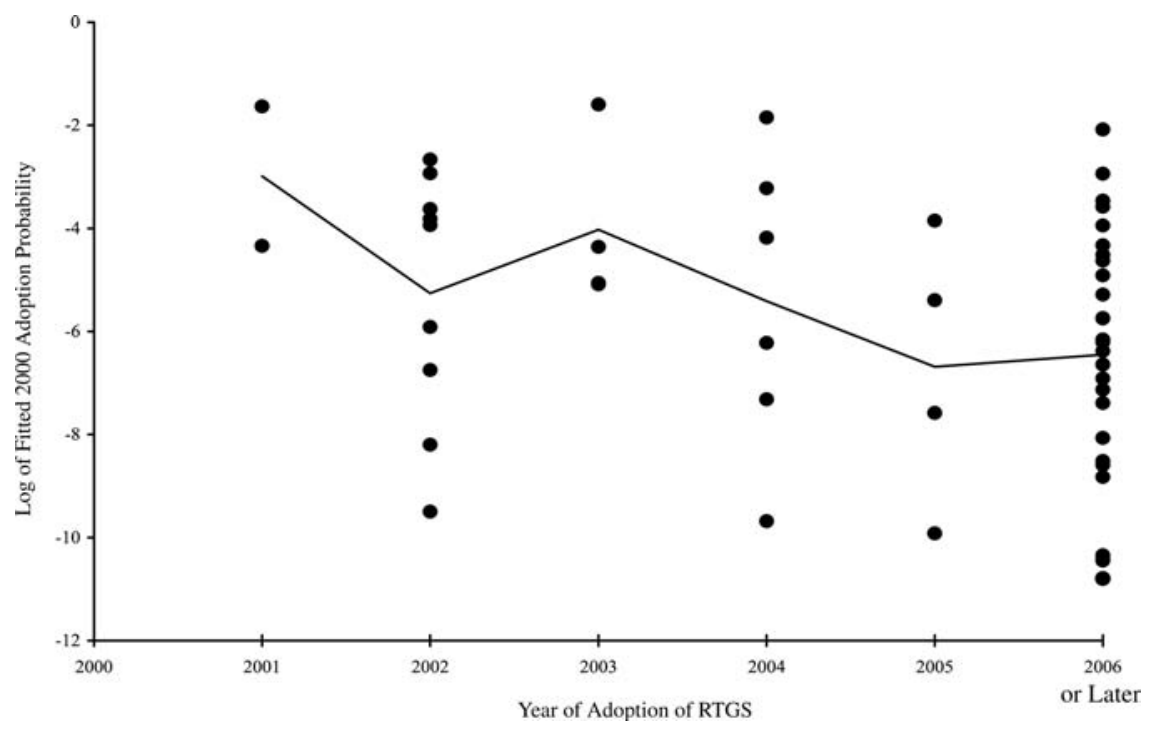


2000 for the countries that adopt in each subsequent year. As can be seen in the figure, later adopters had, on average, a lower fitted probability of RTGS adoption in 2000.

\section{Conclusion}

We study the adoption of real-time gross settlement systems across the world's 174 central banks. These systems are used to facilitate interbank payments. As Frame and White (2004) point out, the rapid rate of financial innovation over the past few decades is widely recognized as a stylized fact. A striking feature of the literature based on this fact, however, is the relative dearth of empirical studies. Ours can be interpreted as one such study. The study of RTGS in the context of technology adoption is interesting, since the decision to adopt RTGS is in large part based on the perception by a central bank of the public goods benefit of the system, rather than on the profit motive driving adoption in the private sector.

The adoption pattern of RTGS follows an S-shaped diffusion curve, similar to that observed for other technologies in technology adoption literature (e.g., Griliches 1957, Mansfield 1961, and Gort and Klepper 1982). The lags in the adoption of RTGS are long. In the last twenty years, the number of central banks using RTGS for their interbank payments has increased from three to ninety-three. This means that eighty-one central banks have not yet adopted RTGS and thus are not yet benefiting from the reduction in settlement risk provided by such a system. Estimation of the world adoption curve of RTGS suggests that it might take another fifteen years before RTGS technology is adopted by the remaining eighty-one central banks.

The probability that a country adopts RTGS in a given year increases significantly with the level of real GDP per capita. Moreover, countries with a lower relative price of capital and countries whose major trading partners have already adopted RTGS are also more likely adopters. This suggests that, beyond market forces reflected by real GDP and capital costs, spillovers seem to play a significant role in the adoption of this financial innovation. These spillovers seem to be transferred mainly through trade relationships.

These results suggest that the policy role of central banks is not only to coordinate the adoption of the RTGS system in their 
domestic market but also to internalize the externalities of this adoption decision by other central banks. International cooperation among central banks is one way to facilitate this internalization. To what extent the RTGS adoption pattern, as well as its determinants, is representative of central banks' technology decisions more broadly is a topic for further research.

\section{Appendix. Data: Sources and Definitions}

\section{Countries and Time Span}

Our data cover the 174 central banks and monetary authorities listed in the 2006 Morgan Stanley Central Bank Directory. The data span a time period from 1970 through 2005. The majority of the central banks in our sample serve only one country. However, the following five central banks encompass various countries: the Eastern Caribbean Central Bank, the Central Bank of West African States (BCEAO), the Central Bank of Central African States (BEAC), the Bank of France, and the Swiss National Bank.

\section{Dependent Variable}

RTGS Adoption: Dichotomous variable that indicates whether or not a central bank has implemented an RTGS system. We gathered information on each central bank's usage of RTGS, as well as the date of implementation, from publicly available web sites.

\section{Explanatory Variables (Listed in Alphabetical Order)}

Bilateral Trade Spillovers: Fraction of trade with top-ten trading partners that is conducted with partners that have implemented RTGS. Source: International Monetary Fund (2006) and Gleditsch (2002). Period: 1970-2005.

BIS Member: Dummy variable that indicates whether country is a member of the BIS. Source: www.correlatesofwar.org. Period: 1970-2005.

Commercial-Central Bank Assets: Assets of deposit-money banks divided by assets of deposit-money banks plus central bank assets. Source: Levine, Loayza, and Beck (2000). Period: 1970-2004. 
Computers: Number of computers per 1,000 people. Source: World Bank (2006). Period: 1980-2003.

Deposits/GDP: Bank deposits as a fraction of GDP. Source: International Monetary Fund (2006). Period: 1970-2004.

Education: Average primary school attainment rate. Source: Barro and Lee (1993). Period: 1970-2000 (average over sample).

Investment Price: Capital goods price index. Source: Heston, Summers, and Aten (2002). Period: 1970-2000.

Liquid Liabilities: Liquid liabilities of the financial system (currency plus demand and interest-bearing liabilities of banks and nonbank financial intermediaries) divided by GDP. Source: Levine, Loayza, and Beck (2000). Period: 1970-2004.

New EU Member: Dummy variable that indicates whether country became a member of the European Union or applied after 1986. Source: www.wikipedia.com (keyword: Union). Period: 1970-2005.

Population: Source: World Bank (2006). Period: 1970-2004.

Private Credit: Credit by deposit-money banks and other financial institutions to the private sector divided by GDP. Source: Levine, Loayza, and Beck (2000). Period: 1970-2004.

Real GDP per Capita: Source: Heston, Summers, and Aten (2002). Period: 1970-2000.

SADC: Dummy variable that indicates whether a country is a member of the South African Development Council. Source: www.sadc.int. Period: 1970-2005.

Note: Not all series are available for every country and every year in our sample.

\section{References}

Akhavein, J., S. Frame, and L. White. 2005. "The Diffusion of Financial Innovations: An Examination of the Adoption of Small Business Credit Scoring by Large Banking Organizations." Journal of Business 78 (2): 577-96.

Allison, P. D. 1982. "Discrete-Time Methods for the Analysis of Event Histories." Sociological Methodology, ed. Samuel Leinhardt, 61-98. San Francisco: Jossey-Bass. 
Angelini, P., G. Maresca, and D. Russo. 1996. "Systemic Risk in the Netting System." Journal of Banking and Finance 20 (5): 853-68.

Ashenfelter, O., and D. Card. 2002. "Did the Elimination of Mandatory Retirement Affect Faculty Retirement?" American Economic Review 92 (4): 957-80.

Bank for International Settlements. 2005. "New Developments in Large-Value Payment Systems." Publication No. 67, Committee on Payment and Settlement Systems.

Barro, R. J., and J. Lee. 1993. "International Comparisons of Educational Attainment." NBER Working Paper No. 4349.

Basu, S., and D. N. Weil. 1998. "Appropriate Technology and Growth." Quarterly Journal of Economics 113 (4): 1025-54.

Bech, M. Forthcoming. "The Diffusion of Real Time Gross Settlement." In The Future of Payments, ed. S. Millard and V. Saporta. London: Routledge.

Bech, M., L. Natorp, and B. Madsen. 2002. "Systemic Risk in the Danish Interbank Netting System." Working Paper No. 8, Danmarks Nationalbank.

Blix, M., S. Daltung, and L. Heikensten. 2003. "On Central Bank Efficiency." Economic Review (Sveriges Riksbank) 3: 81-93.

Brione, P. 2006. "Central Bank Staff Costs." Central Banking XVI (2): 69-74.

Brynjolfsson, E., and L. M. Hitt. 2000. "Beyond Computation: Information Technology, Organizational Transformation and Business Performance." Journal of Economic Perspectives 14 (4): 23-48.

Caselli, F., and W. J. Coleman. 2001. "Cross-Country Technology Diffusion: The Case of Computers." American Economic Review 91 (2): 328-35.

Coe, D. T., and E. Helpman. 1995. "International R\&D Spillovers." European Economic Review 39 (5): 859-87.

Comín, D., and B. Hobijn. 2004. "Cross-Country Technology Adoption: Making the Theories Face the Facts." Journal of Monetary Economics 51 (1): 38-83.

Frame, W. S., and L. J. White. 2004. "Empirical Studies of Financial Innovation: Lots of Talk, Little Action?" Journal of Economic Literature 42 (1): 116-44.

Gleditsch, K. S. 2002. "Expanded Trade and GDP Data." Journal of Conflict Resolution 46 (5): 712-24. 
Goolsbee, A., and P. Klenow. 2002. "Evidence on Learning and Network Externalities in the Diffusion of Home Computers." Journal of Law 83 Economics 45 (2): 317-44.

Gort, M., and S. Klepper. 1982. "Time Paths in the Diffusion of Product Innovations." Economic Journal 92 (367): 630-53.

Gowrisankaran, G., and J. Stavins. 2004. "Network Externalities and Technology Adoption: Lessons from Electronic Payments." RAND Journal of Economics 35 (Summer): 260-76.

Griliches, Z. 1957. "Hybrid Corn: An Exploration in the Economics of Technological Change." Econometrica 25 (4): 501.

Hannan, T. H., and J. M. McDowell. 1984. "The Determinants of Technology Adoption: The Case of the Banking Firm." RAND Journal of Economics 15 (3): 328-35.

Heston, A., R. Summers, and B. Aten. 2002. "Penn World Table Version 6.1." Center for International Comparisons at the University of Pennsylvania (CICUP).

Humphrey, D. B. 1986. "Payments Finality and Risk of Settlement Failure." Technology and the Regulation of Financial Markets: Securities, Futures, and Banking, ed. A. Saunders and L. J. White. Lexington, MA: D. C. Heath and Company.

International Monetary Fund. 2006. International Financial Statistics (IFS). Online Database. Washington, DC: International Monetary Fund.

Jensen, R. 1982. "Adoption and Diffusion of an Innovation of Uncertain Profitability." Journal of Economic Theory 27 (1): 182-93.

Jones, C. I. 1994. "Economic Growth and the Relative Price of Capital." Journal of Monetary Economics 34 (3): 359-82.

- 1995. "R\&D-Based Models of Economic Growth." Journal of Political Economy 103 (4): 759-84.

Jovanovic, B., and S. Lach. 1989. "Entry, Exit, and Diffusion with Learning by Doing." American Economic Review 79 (4): 690-99.

Kahn, C. M., J. McAndrews, and W. Roberds. 2003. "Settlement Risk under Gross and Net Settlement." Journal of Money, Credit, and Banking 35 (4): 591-608.

Keller, W. 2004. "International Technology Diffusion." Journal of Economic Literature 42 (3): 752-82.

Lester, B., S. Millard, and M. Willison. 2006. "Optimal Settlement Rules for Payment Systems." Mimeo, Bank of England. 
Levine, R., N. Loayza, and T. Beck. 2000. "Financial Intermediation and Growth: Causality and Causes." Journal of Monetary Economics 46 (1): 31-77.

Mansfield, E. 1961. "Technical Change and the Rate of Imitation." Econometrica 29 (4): 741-66.

McAndrews, J., and J. Trundle. 2001. "New Payment System Designs: Causes and Consequences." Financial Stability Review (Bank of England) 11 (December): 127-36.

Morgan Stanley. 2006. Central Bank Directory. London: Central Banking Publications.

Nelson, R. R., and E. S. Phelps. 1966. "Investment in Humans, Technological Diffusion, and Economic Growth." American Economic Review 56 (2): 69-75.

Richards, F. J. 1959. "A Flexible Growth Curve for Empirical Use." Journal of Experimental Botany 10 (2): 290-300.

Rogers, E. 1995. Diffusion of Innovations. 5th ed. New York: Free Press.

Selgin, G. 2004. "Wholesale Payments: Questioning the MarketFailure Hypothesis." International Review of Law and Economics 24 (3): 333-50.

Skinner, J., and D. Staiger. 2005. "Technology Adoption from Hybrid Corn to Beta Blockers." NBER Working Paper No. 11251.

World Bank. 2006. World Development Indicators (WDI). Online Database. Washington, DC: World Bank Group. 
